\title{
The European plant tissue culture industry - 1990
}

\author{
F Ó Ríordáin
}

Kinsealy Research and Development Centre, Malahide Road, Dublin 17, Ireland

(COST Meeting, 21-23 May 1992, Dijon, France)

\begin{abstract}
Summary - The COST $87^{*}$ management committee carried out a third survey of European plant tissue culture laboratories in 1990. The information from each country was collected by the national representative on the committee on query forms which were completed and returned to the author. The results were computerised and analysed using SAS and the directory published by the commission (Ó Ríordáin, 1991). The published information consisted of the laboratory location, person to contact and work in progress on different plants. In addition, the location of 1014 people in the industry was given. The additional information collected was used as the basis for this article and was not included in the directory.
\end{abstract}

survey / directory / micropropagation / plant tissue culture

Résumé - L'industrie européenne de la culture des tissus végétaux. Le comité de gestion du COST 87 a mené en 1990 une troisième enquête sur les laboratoires de culture de tissus européens. L'information a été réunie pour chaque pays par le représentant national au comité, et reportée sur des formulaires qui nous ont été envoyés. Les données ont été traitées par ordinateur en utilisant SAS et l'annuaire a été publié par la commission (Ó Riordáin, 1991). L'annuaire indique, pour chaque cas, l'emplacement du laboratoire, la personne à contacter et les recherches en cours sur différentes plantes. Par ailleurs, le lieu d'activité de 1014 personnes travaillant dans cette discipline est indiqué. Le reste de l'information réunie est utilisé dans le présent article et n'est pas inclus dans l'annuaire.

enquête / annuaire / micropropagation / culture de cellules végétales

\section{INTRODUCTION}

Information was received from 427 laboratories in 17 countries. Most of this related to 1990 except for numbers of plants produced which was for 1989. There was a considerable increase in most countries in the number of both commercial and official laboratories during the 2-yr period between this survey and the preceding one (Ó Ríordáin, 1988) (table I). The number of commercial laboratories increased by a factor of $\approx 3.5$, while official laboratories increased by $\approx 4$ since the first survey in 1982 (Ó Ríordáin, 1982) (fig 1).

\section{PLANTS}

The 30 most cited genera from commercial laboratories are listed in table II, while those cited by official laboratories are shown in table III.

As in 1988, Prunus was again the most important plant genus, being top of both the commercial and official lists. Prunus was cited a total of 285 times. The second most important genus for commercial laboratories was Ficus, as in 1988. New to this list were orchids at position 9, and Cynara and Beta, with 25 and 27 citations respectively. The most dramatic increase in importance was shown by Brassica, while the

\footnotetext{
- The COST programme is an action of European co-operation and encompasses the member states of the European Community and Austria, Finland, Norway, Sweden, Switzerland, Turkey and Yugoslavia. COST 87 is a research programme of "Plant in Vitro Culture" initially implemented in the framework of BAP (Multiannual Research Action Programme of the European Economic Community in the Field of Biotechnology) and subsequently in BRIDGE (Biotechnology Research for Innovation, Development and Growth in Europe). COST 87 resulted from a suggestion made to the COST senior officials by the Swiss delegation.
} 
Table I. Distribution of returns for the 1990 European plant tissue culture laboratory survey and comparison with those of 1988.

\begin{tabular}{ccccc}
\hline Code Country & Official & Commercial Total \\
1988 & 1990 & 19881990 & 1990 \\
\hline
\end{tabular}

\begin{tabular}{lrrrrr} 
A Austria & 6 & 6 & 2 & 0 & 6 \\
B Belgium & 17 & 22 & 8 & 11 & 34 \\
DK Denmark & 1 & 6 & 3 & 6 & 12 \\
SF Finland & 10 & 21 & 3 & 6 & 27 \\
F France & 14 & 33 & 12 & 25 & 58 \\
D Germany & 20 & 28 & 15 & 25 & 53 \\
GR Greece & 3 & 14 & 4 & 6 & 20 \\
IRL Ireland & 8 & 9 & 1 & 4 & 13 \\
I Italy & 11 & 18 & 23 & 27 & 45 \\
NL Netherlands & 25 & 19 & 25 & 35 & 54 \\
N Norway & 5 & 6 & 1 & 2 & 8 \\
P Portugal & 2 & 11 & 0 & 2 & 13 \\
E Spain & 15 & 8 & 22 & 11 & 19 \\
S Sweden & 2 & 3 & 4 & 4 & 7 \\
CH Switzerland & 5 & 6 & 6 & 8 & 14 \\
UK United Kingdom & 10 & 36 & 8 & 7 & 43 \\
Yu Yugoslavia & - & 1 & - & - & 1 \\
& & & & & \\
Total & 154 & 248 & 137 & 180 & 421 \\
& & & & & \\
\hline
\end{tabular}

Table II. The Plant genera in order of importance with the numbers of commercial laboratories working on them.

\begin{tabular}{lrll}
\hline Genus & $\begin{array}{c}\text { No of } \\
\text { laboratories }\end{array}$ & Genus & $\begin{array}{c}\text { No of } \\
\text { Laboratories }\end{array}$ \\
\hline Prunus & 107 & Rubus & 25 \\
Ficus & 82 & Actinidia & 24 \\
Philodendron & 56 & Saintpaulia & 24 \\
Spathiphyllum & 46 & Pyrus & 22 \\
Nephrolepis & 44 & Syringa & 22 \\
Rosa & 41 & Anthurium & 19 \\
Syngonium & 37 & Pelargonium & 19 \\
Malus & 35 & Betula & 18 \\
Orchideaceae & 31 & Rhododendron & 17 \\
Solanum & 30 & Cynara & 14 \\
Cordyline & 28 & Lilium & 14 \\
Begonia & 27 & Beta & 12 \\
Gerbera & 27 & Dianthus & 12 \\
Brassica & 26 & Hydrangea & 12 \\
Fragaria & 26 & Dieffenbachia & 11 \\
& & Gardenia & 11 \\
\hline & \multicolumn{3}{l}{} \\
\hline
\end{tabular}

largest decrease in importance was shown by Fragaria.

With the official laboratories the largest increase in importance was Vitis, in fourth position, followed by Daucus, Nicotiana and Pyrus. The first 2 possibly pointed to a new emphasis on more basic research in attempting to obtain a better understanding of the mechanisms of plant development in tissue culture. Saintpaulia and Dianthus showed large decreases in the number

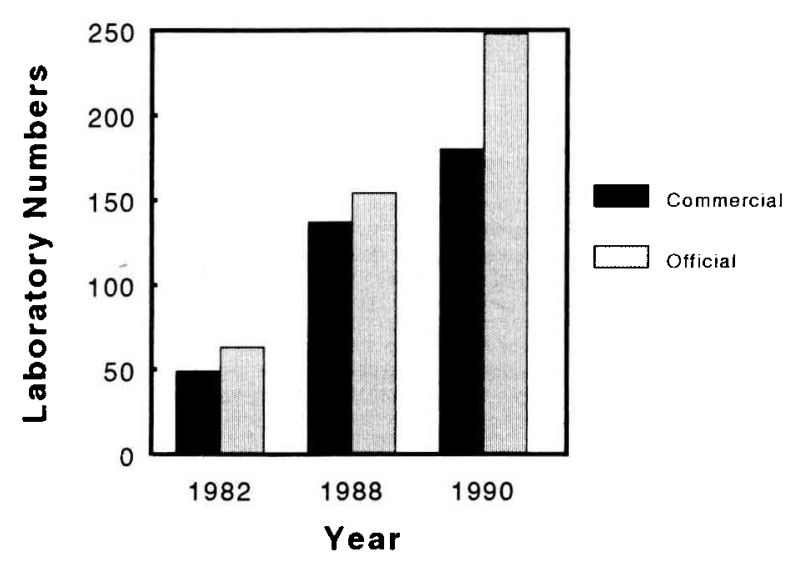

Fig 1. Numbers of laboratories in COST 87 surveys.

Table III. The Plant genera in order of importance for official laboratories.

\begin{tabular}{lclc}
\hline Genus & $\begin{array}{c}\text { No } \\
\text { laboratories }\end{array}$ & Genus & $\begin{array}{c}\text { No } \\
\text { laboratories }\end{array}$ \\
\hline Prunus & 78 & Dianthus & 19 \\
Solanum & 66 & Daucus & 18 \\
Malus & 62 & Triticum & 18 \\
Vitis & 42 & Begonia & 16 \\
Brassica & 40 & Beta & 16 \\
Nicotiana & 39 & Citrus & 16 \\
Betula & 37 & Daphne & 14 \\
Rosa & 35 & Hordeum & 14 \\
Quercus & 32 & Petunia & 14 \\
Fragaria & 25 & Pinus & 14 \\
Pyrus & 23 & Populus & 14 \\
Pelargonium & 22 & Saintpaulia & 14 \\
Rhododendron & 22 & Coffea & 13 \\
Ficus & 21 & Helianthus & 13 \\
Rubus & 20 & Orchideacae & 13 \\
Allium & 19 & Syringa & 13
\end{tabular}


of official laboratories working on them, suggesting that these plants no longer presented technical problems (Dianthus also showed a similar decrease in importance in commercial laboratories). The interest in forest trees continued, with the addition of Pinus to the list. It is also interesting to note the increasing importance of cereals, with Triticum and Hordeum included on the official laboratories list. Coffee was an interesting and new addition to the list for European laboratories.

\section{LABORATORY SIZE}

The survey showed a total of 3176 people working in the plant tissue culture industry (table IV).

While this is a small rise in the corrected figures, there was a decrease in the mean number of people per laboratory, which suggested that the increase in the number of laboratories had mostly been in small units. On the other hand, $30 \%$ of commercial laboratories employed 1-3 people - an improvement on the $38 \%$ in 1988 , while $32 \%$ of official laboratories were of that size. Also there was some transfer of production to low income countries.

Since 1988 there was a decrease of $9 \%$ in the number of commercial laboratories with 1 and 2 persons, while those employing 3-7 people increased by $15 \%$. At the other end of the scale, there was a decrease of $6 \%$ in the number of laboratories with $>50$ employees. The total number of people employed in 9 of the countries involved is shown in figure 2.

The mean number of clean work stations in commercial laboratories showed a small increase from 7.5 to 8 , which may indicate a higher level of investment; $41 \%$ of commercial laboratories had 1-3 clean benches, again an improvement

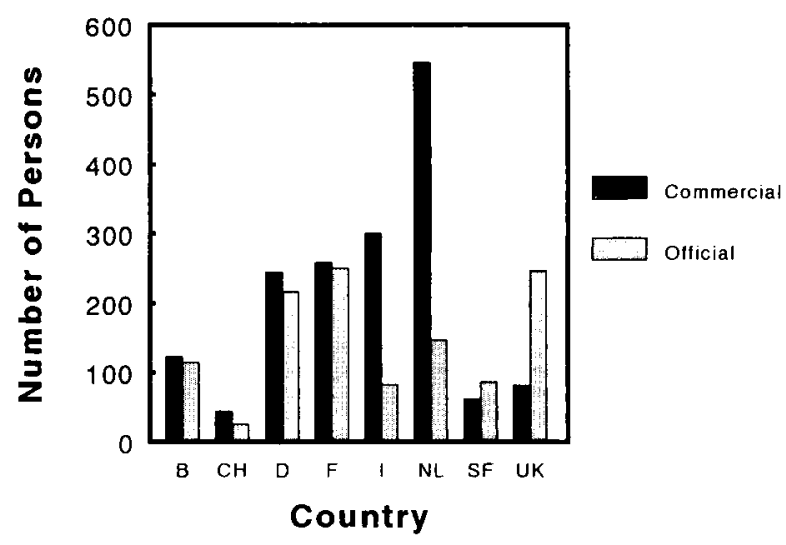

Fig 2. Persons in the plant tissue culture industry.
Table IV. Number of people in the European plant tissue culture industry.

\begin{tabular}{lrrr}
\hline & $\begin{array}{c}\text { Commercial } \\
\text { laboratories }\end{array}$ & Official & Total \\
\hline Number & 1781.0 & 1395.0 & 3176.0 \\
Estimated total & 1887.0 & 1508.0 & 3395.0 \\
Mean/laboratory & 10.5 & 6.1 & 8.0 \\
\hline
\end{tabular}

Table V. Total plants produced in 1990 (millions).

\begin{tabular}{lrrr}
\hline & $\begin{array}{c}\text { Commercial } \\
\text { laboratories }\end{array}$ & Official & Total \\
& & & \\
\hline Numbers reported & 154.40 & 4.00 & 158.40 \\
Estimated total & 175.20 & 6.00 & 181.20 \\
Mean/laboratory & 0.98 & 0.02 & 0.42 \\
\hline
\end{tabular}

on the $46 \%$ in 1988 . The distribution of clean work stations in 8 countries is shown in figure 3 .

\section{PLANTS PRODUCED}

The number of plants produced per year by commercial laboratories ranged from 1000 to 11.6 million. The largest individual production by a single laboratory showed an increase from 8 million in 1988 to 11.6 million in 1990 . The estimated total production for the commercial sector was 181.2 million plants, which was in close agreement with the figure of 212.5 million total production for Europe, as published by Pierik (1991) (table V). He found 37 commercial labor-

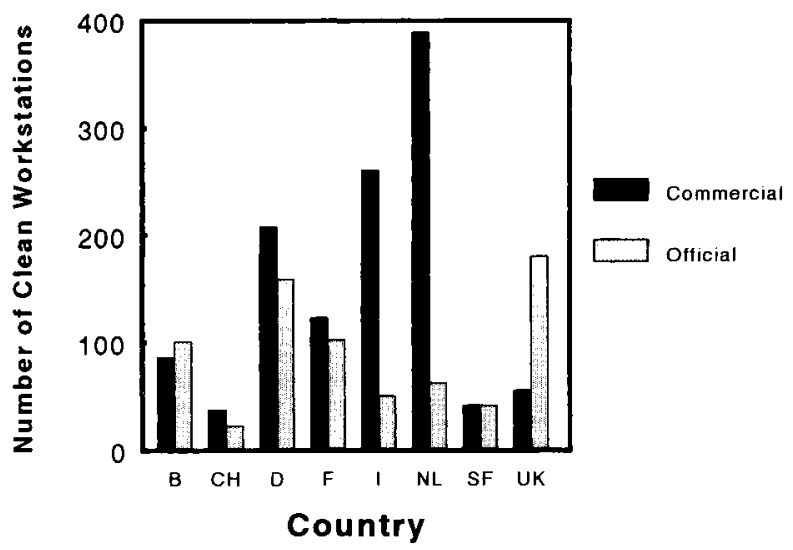

Fig 3. Distribution of clean work stations. 
atories out of 214 with a total production of $>10^{6}$ plants. In this survey, 39 laboratories out of the 157 that supplied figures had a production of $>10^{6}$. With a mean price of $0.3 \mathrm{ECU}$ per plant, commercial production would be valued at $>54$ MECU. The total numbers of plants produced in the main production countries are shown in figure 4. Totals for the different plants produced in commercial laboratories in 1990, neglecting those entries without figures, are shown in table VI. Gerbera was highest with $>18.10^{6}$ produced; Nephrolepis was second with $14.5 .10^{6}$.

\section{MAIN INTERESTS OF LABORATORIES}

The primary interests of laboratories, both commercial and official are compared in figure 5. Rapid multiplication (RM) was the most important factor in both sectors. It accounted for $75 \%$ of the commercial and $36 \%$ of the official labora-

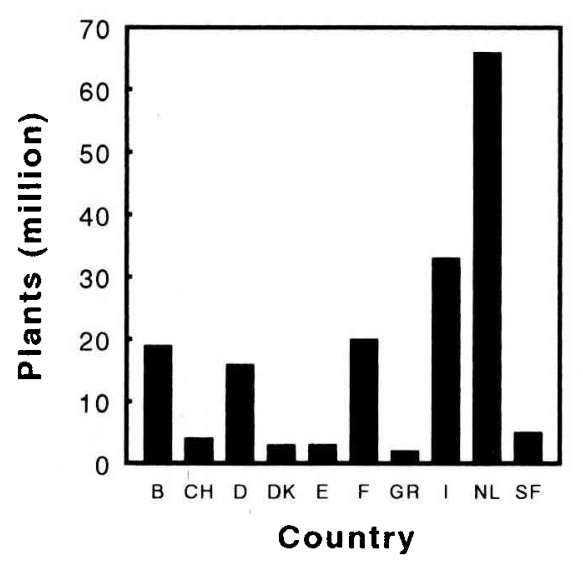

Fig 4. Numbers of plants produced by country.

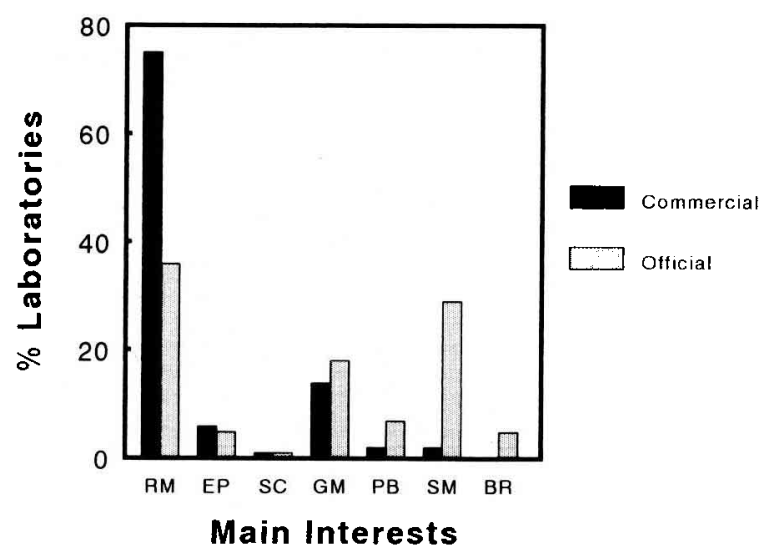

Fig 5. Main interest of laboratories. RM: Rapid multiplication; EP: elimination of pathogens; SC: storage of cultures; GM: genetic manipulations; PB: plant breeding; SM: production of secondary metabolites; BR: basic research).
Table VI. Totals of plants produced in commercial laboratories (x 1000$)$.

\begin{tabular}{lrlr}
\hline & & & \\
Gerbera & 18383 & Vriesea & 2805 \\
Nephrolepis & 14517 & Orchidaceae & 2162 \\
Prunus & 10725 & Philodendron & 2138 \\
Spathiphyllum & 9827 & Citrus & 2061 \\
Lillium & 7112 & Pyrus & 1805 \\
Fragaria & 7040 & Begonia & 1726 \\
Ficus & 7002 & Cordyline & 1175 \\
Saintpaulia & 5985 & Actinidia & 1112 \\
Cynara & 5727 & Beta vulgaris & 1070 \\
Rosa & 5696 & Rubus & 1009 \\
Syngonium & 4797 & Kalmia & 1001 \\
Anthurium & 4408 & Betula & 842 \\
Triticum & 4016 & Nicotiana & 704 \\
Rhododendron & 3882 & Platycerium & 700 \\
Solanum tuberosum & 2817 & Dieffenbachia & 682 \\
\hline
\end{tabular}

tories. The balance was reversed with genetic manipulation (GM), plant breeding (PB) and the production of secondary metabolites (SM). No commercial firms were primarly interested in basic research (BR), while interest in elimination of pathogens (EP) and culture storage (CS) were equal in both sectors.

\section{ACKNOWLEDGMENTS}

The author wishes to thank all those at the different tissue culture laboratories who took the trouble to fill in the forms; and the national representatives on the management committee of COST 87 who organised the distribution and collection of the forms. In addition, he wishes to thank T Hegarty for statistical analysis.

\section{REFERENCES}

Ó Ríordáin F (1982) COST 87, Directory of European Plant Tissue Culture Laboratories, 1982. Commission of the European Communities, Brussels

Ó Ríordáin F (1988) COST 87, Directory of European Plant Tissue Culture Laboratories. Commission of the European Communities, DG XII, Brussels, pp 74

Ó Ríordáin F (1991) COST 87, Directory of European Plant Tissue Culture Laboratories, 1990. Commission of the European Communities, DG XII, Brussels, pp 124

Pierik RPM (1991) Commercial micropropagation in western Europe and israel. In: Micropropagation: Technology and Application (Debergh PC, Zimmerman $\mathrm{RH}$, eds) Kluwer Academic Publ, The Netherlands, 155-165 